\title{
Biochemical efficacy and safety trial of vitamin $D$ (BEST-D): finding an appropriate dose to test in a large randomized trial
}

\author{
Jane Armitage ${ }^{1 *}$, Harold Hin², Joseph Tomson ${ }^{1}$, Mike Lay ${ }^{1}$, Mike Hill ${ }^{1}$, Robert Clarke \\ From 2nd Clinical Trials Methodology Conference: Methodology Matters \\ Edinburgh, UK. 18-19 November 2013
}

Understanding the shape and strength of risk factor associations with disease in observational studies is essential for the successful design of risk factor-modification trials. Observational studies show that low plasma levels of 25-hydroxy vitamin D (25[OH]D), a blood marker of vitamin D status, are linearly related with bone mineral density and fractures, in addition to higher risks of vascular and non-vascular mortality. Over the last 20 years, several trials of vitamin D3 have assessed the effects of supplementation with equivalent daily doses of 400-800 IU on risk of fracture, but results have been conflicting. A meta-analysis of such trials reported a $14 \%$ (95\% CI 4-23\%) reduction in non-vertebral fractures, but the results suggest that plasma levels of $25[\mathrm{OH}] \mathrm{D}$ need to be at least $80-90 \mathrm{nmol} / \mathrm{L}$ to provide fracture protection. Moreover, previous trials also indicate an average increase of only about 7-10 nmol/L in plasma 25[OH]D for each $400 \mathrm{IU}$ of vitamin D3 given daily. Consequently, at least $2000 \mathrm{IU}$ daily may be required to increase plasma levels of $25(\mathrm{OH}) \mathrm{D}$ from an average winter level of $30 \mathrm{nmol} / \mathrm{L}$ (typical in the UK) to $90 \mathrm{nmol} / \mathrm{L}$, suggesting that the previous trials have used insufficient doses of vitamin D3 to detect the epidemiologically predicted differences in clinical outcomes. To help determine the optimum dose of vitamin D3 for prevention of fractures and other health outcomes, we are comparing the biochemical efficacy and safety of 2000 and 4000 IU daily (versus placebo) vitamin D3 in a pilot study of 305 healthy people aged $>65$ years.

\section{Authors' details}

'University of Oxford, Oxford, UK. ${ }^{2}$ Hightown Surgery, Banbury, UK.

'University of Oxford, Oxford, UK

Full list of author information is available at the end of the article
Published: 29 November 2013

doi:10.1186/1745-6215-14-S1-P45

Cite this article as: Armitage et al.: Biochemical efficacy and safety trial of vitamin D (BEST-D): finding an appropriate dose to test in a large randomized trial. Trials 2013 14(Suppl 1):P45.
Submit your next manuscript to BioMed Central and take full advantage of:

- Convenient online submission

- Thorough peer review

- No space constraints or color figure charges

- Immediate publication on acceptance

- Inclusion in PubMed, CAS, Scopus and Google Scholar

- Research which is freely available for redistribution
C Biomed Central

\section{Biomed Central}

